\title{
Reports of Investigation Characteristics of good anaesthesia teachers
}

Doreen Cleave-Hogg PhD, Christina Benedict MD

Purpose: The Department of Anaesthesia undertook a qualitative study to a) reveal the characteristics of teachers who had been identified as "good," and b) explore the levels of epistemological development (defined as conceptualization of knowledge) that are evidenced. Changes in medical education curricula have focused attention on the ways in which medical teaching staff conceptualize the learningfeaching interactions and their ability to alter or modify their teaching styles. Teachers are often assessed or informally recognized as "good teachers." but there are few indicators to guide what is meant by the label in anaesthesia.

Methods: Teachers who had consistently received overall ratings of $4+$ on a 5 point rating scale over a five year period were selected to be interviewed. Data were analyzed a) noting key teaching characteristics and pattems of teaching and $b$ ) within the framework of adult development theories.

Results: Good teachers in Anaesthesia all identified six characteristics necessary for good teaching. They were characterised by their "inquiry" approach to teaching, their complexity of thought and their functioning at higher relativistic/Commitment levels of epistemological development.

Conclusion: Teaching in anaesthesia is depicted by the need to address multiple aspects of thinking and action. Good teachers are aware of these aspects and include techniques that offer residents opportunities to develop their thinking skills to deal with medical complexities as well as guiding learners to increase their knowledge. The interviewed teachers' revealed approaches to teaching and learning that indicated their own personal cognitive complexity and levels of development.

Objectif : Le département d'anesthésie a entrepris cette étude qualitative dans le but a) de trouver les caractéristiques du professeur identifié comme «bon», et b) d'explorer les niveaux de développement épistémologique (défini comme la conceptualisation du savoir) qu'il met en relief. Les changements de curriculum en éducation médicale ont attiré l'attention sur les façons utilisées par le personnel enseignant pour conceptualiser les interactions entre l'apprentissage et l'enseignement et sur son aptitude à changer sa manière d'enseigner. En anesthésie. les enseignants sont souvent évalués ou qualifiés de façon non formelle comme abons professeurs» sans qu'on ne sache trop pourquoi ce qualificatif est attribué.

Méthodes : Les enseignants qui avaient reçu une cote globale de $4+$ sur une échelle de cinq points pendant une période de cinq ans ont été interrogés. Les données recueillies ont été analysées a) en prenant note des caractéristiques et du pattern de l'enseignement et b) du contexte des théories de développement de l'adulte.

Résultats : En anesthésie, tous les «bons» professeurs ont identifiés six caractéristiques jugées essentielles au bon enseignant. Ils reconnaissaient leur approche interactive à l'enseignement, la complexité de leur pensée et leur fonctionnement à des niveaux de relativisme/engagement plus élevés de développement épistémologique.

Conclusion : L'enseignement en anesthésie est décrit par le besoin d'aborder les multiples facettes du raisonnement et de l'action. Les bons professeurs les connaissent et utilisent des techniques qui offrent aux résidents l'opportunité de développer leur aptitudes intellectuelles pour affronter les complexités de la médecine; ils servent de guides dans la voie de l'acquisition de la connaissance. Les enseignants interviewés ont révélé des approches au savoir et à l'enseignement qui illustrent leur complexité cognitive et leur niveau de développement.

From the Department of Anaesthesia, University of Toronto Centre for Research in Education, MSB 2311, 1 Kings College Circle, Toronto, ON M5S 1A8.

Address correspondence to: Dr. Cleave-Hogg; Phone: 416-978-8335; Fax: 416-978-7186; E-mail: d.cleave@utoronto.ca Accepted for publication March 7, 1997. 


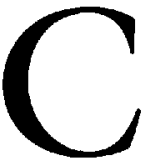

HANGES in medical education curricula have focused attention on the ways in which medical teaching staff conceptualize the learning/teaching interactions and their ability to alter or modify their teaching styles. It has been suggested that much depends on the teachers' self-motivation or institutional leadership ${ }^{1}$ and that successful planning includes these concepts. Another approach is to develop an awareness of the epistemological development of individual teaching faculty and their attitudes towards teaching. ${ }^{2-5}$ That is, the way an individual views knowledge, its acquisition, application and assessment and how these views relate to the integration of knowledge in life's tasks. The results of a survey of faculty teaching in the first two years of an undergraduate medical programme indicated a wide range of developmental profiles and diverse views regarding content, teaching, learning environments, evaluation and ethical issues. ${ }^{6}$ Yet, in spite of the diversity, the attitudes and aptitudes of teaching staff are central to education and predict their behaviour in teaching situations. ${ }^{7}$ Students' perceptions of 'ways of knowing' also impact on the learning process and studies indicate that many medical students enter and remain at the lower levels of cognitive development. ${ }^{8,9}$ The challenge is to identify the characteristics of an environment that optimizes the learning potential of students and enables them to develop the ability to deal with uncertainty, diversity and complexity.

In order to explore more fully the question "What characteristics exemplify a good teacher?," a qualitative study was undertaken in the Department of Anaesthesia at a large medical college.

Theories of epistemological development provide the framework for the questioning protocol for interviews and analysis of data in this study. The studies of Perry, ${ }^{2}$ Basseches, ${ }^{3}$ Sinnot ${ }^{4}$ and others guided the design of the project.

Briefly, Perry identifies nine developmental positions (avoiding the hierarchical notion of stages) that students are likely to attain. He differentiates the first five positions in terms of their differing assumptions of knowledge, followed by four positions of refinement and commitment. Positions $1-2$ are characterised by a dualistic perspective; the world is seen in polar terms of we-right-good ps other-wrong-bad. Knowledge is viewed as quantitative, the memorization of accumulated facts; they do not accept diversity and uncertainty, which are seen only as indicators of an authority's (teachers') lack of knowing/facts. Through positions 3-4 there is a growing awareness and acceptance of diversity but views are characterised by multiplicity.
That is, authority's realm of the absolute (right $v s$ wrong) still prevails but this is tempered by a person's notion that "my opinion is a good as anyone's" without the understanding of the need for reasoning structures. Position $\mathbf{5}$ is characterised by relativistic and contextual thinking that views knowledge as qualitative; knowledge is not given but is personally constructed and the responsibility of this process lies with the learner. Positions 6-9 are refinements of relativistic thinking, with individuals making a personal Commitment (Perry depicts this with a capital $\mathrm{C}$ ) as an ongoing, developing process that underpins a personal life-style and professional vocations. Commitment, according to Perry, ${ }^{2}$ "is an affirmation of personal values and (in the context of describing a position) is reserved for an integrative, affirmative function; (it is) a conscious act of identity and responsibility in a relative world."

Delworth and Piel ${ }^{10}$ argue that one must study the nature of an environment (which includes teachers) in order to understand the development of students' learning. A positive educational climate is one that promotes greater complexity of thinking with which to understand and act on professional and life tasks and problems. Yet this can only be achieved if professors themselves have attained a holistic view of the learning environment and model higher levels of learning. The challenge is to identify teaching characteristics that promote optimal learning in specific contexts.

\section{Methods}

Using qualitative research methodology ${ }^{11,12} 14$ of the Anaesthesia faculty (nine men, five women) were selected to be interviewed. The selection was determined by 1) examination of residents' evaluations of faculty over a five-year period, 2) examination of clerks' evaluations of faculty, and 3) recommendations of the Department Chair and Directors of medical education. Faculty who were identified as 'good teachers' on the three lists were selected. All selected faculty agreed to be interviewed but one was omitted due to scheduling problems. Each teacher was interviewed by one educational researcher (first author) for approximately $60 \mathrm{~min}$. The interview protocol consisted of open-ended questions that focused on the teacher's view of learning, education, teaching and assessment. Personal philosophies of education and teaching goals were explored and practical examples solicited. All sessions were tape-recorded and later transcribed and coded using the computer programme The Ethnograph ${ }^{13}$ to facilitate categorization, coding, sorting and reporting. Data were first analyzed to identify similarities among the responses and to identify trends in approaches to teaching and learn- 
ing; the data were then analyzed within the framework of epistemological development theory by a trained assessor (DC-H).

\section{Results}

The data indicated that interviewees' perceptions of what made them good teachers were relatively consistent. Characteristics that they identified (but not prioritized) were

- dedication

- commitment

- enthusiasm for teaching

- willingness to give time to teaching

- enjoyment of one's own profession

- understanding self as a role-model

- motivation to upgrade and enrich one's own learning continually

- ability to establish and maintain interactive professional relationships.

In general, the approach to teaching encompassed helping the resident develop complex thinking skills as well as acquiring new knowledge. They made expressed efforts to balance the need to impart scientific knowledge, challenge assumptions, guide experiential learning and, at the same time, ensure patient care and safety. They all saw themselves as role-models and considered this to be an essential component for teaching and learning.

\section{Teaching in the operating room}

Faculty used both the inquiry model of teaching, describing their efforts to get residents to think through complex situations by using Socratic questioning, and the apprenticeship model which encouraged residents to learn through experiential and observational methods followed by reflection and assessment. The following teacher self-initiated guidelines were stated as important components for an effective learning experience:

- Identify the resident's basic level of knowledge

- Help the resident develop an OR action/organization plan

- Start with current medical case and review the resident's organizational plan

- Challenge the resident to be prepared for the unexpected

- Direct the resident to reflect on organization and implementation of a plan

- Provide immediate and honest feedback in a constructive manner

These teachers stated that they avoided confrontation; avoided leaving residents without supervision; and made great efforts to follow through on tasks given to residents that were intended to improve a resident's performance in specific areas.

In describing their teaching methods these anaesthetists gave many references to "keeping the whole body in mind" and "that the lungs, heart, kidneys, brain and so on must be working together" and "you can never ignore any of the systems." They also used imagery to describe the concept. For example;

It is like flying an airplane, knowing you bave to keep alert to all parts, conditions and variables.

Another used the analogy of an orchestra;

All the parts have to keep in tune and in rbythm and one can never lose track of even the smallest note if the overall outcome is to be optimal.

It was this holistic approach that set the theme for other discussion regarding OR teaching. There was a need to ensure that each resident develop "a structure," "an organizational pattern," "a sequential strategy" that would provide a foundation for all cases.

I tell them what I am doing, how I organize my thinking, show them why it is necessary to do this and how things can be missed if the approach is not organized. You have to learn this down pat and not forget any of the steps or parts.

All interviewees emphasized that an organizational pattern is modelled by the teacher but they also acknowledged that there were a variety of patterns among the staff. It was expected that each resident would develop a personal organizational pattern after experiencing a variety of models. Once this structure is in place the particulars of a case, be they simple or complex, are addressed and problem solving skills mobilised.

Teachers developed learning episodes from individual cases and asked residents to articulate their reasoning process and reflect on decisions concerning the problem. Much depended on the type of case confronting the resident. Quick cases gave no time for teaching, "the patient is in and out (of the OR) before you can develop any discussion." Complex cases defined the issues to be dealt with and discussion centred on the need for action and judgment. Simple but lengthy cases provided time for the staff person to question the resident more profoundly and to expand on possible complications and complexities. Urgent cases made it necessary to focus on the patient's needs.

All interviewees stated the need to challenge the residents' thinking. One anaesthetist referred to his technique as "anticipation questioning," another to the 
"what if" scenario. For example, "what if this woman were pregnant?" "What if the surgeon suddenly calls out, "We're losing a lot of blood here"? The aim of all the interviewees was to help the resident think through and be prepared for many different developments.

\section{Concerns}

When asked what they perceived as difficulties in teaching, the faculty all identified "giving feed-back" as one of the major areas of concern for them.

I know that feedback is critical but when I am in some situations I find it difficult to find the right approach, the right words that will make the resident understand that what they are doing needs to change - yet not make the resident, well, feel put down. It is very difficult to find the best approach.

Concrete examples were easiest to deal with but attitudinal, ethical, communication and relationship skills were viewed by all interviewees as more difficult to assess and comment upon. Part of this concern was linked by some faculty to their desire "not to be confrontational," "to be viewed as helpful" or "I don't want to sound as if I keep putting them (residents) down."

Another area of concern was related to the difficulties encountered in trying to balance the clinical, research, teaching and administrative demands of their professional life. For some, this balance was expanded to include personal, family and community responsibilities. "How to make time" was the niggling consideration for eight of the interviewees.

\section{Epistemological development}

Analysis of the data from the perspective of Perry's developmental schema indicated that all the 'good teachers' were functioning at $5+$ levels. That is, they viewed knowledge as from relativistic perspectives, acknowledging that learners must construct their knowledge through the interactions with teachers who role-model both concrete, practical clinical performance, inquiring minds and openness to new knowledge and ideas.

Interestingly, many questioned their selection as one of the top rated teachers stating that they saw their need to improve their teaching. Some discussed the need for educational development and their interest in attending workshops and seminars in education; others described personal innovations that had been introduced and efforts to improve in very specific areas such as introducing a new concept or linking practical experience to basic sciences. They all thought that, regardless of the high evaluation ratings received, they still had much to learn and were keen to improve.

\section{Discussion}

Our research indicates that the Anaesthesia teachers interviewed have a holistic approach to education. Their methods, though individualistic, can be generally described as an inquiry mode, with much emphasis placed on open-ended questioning designed to challenge the resident to think through outcome variables, care options and crisis management. Their goals reflect what Armour and Furman ${ }^{14}$ describe as goals for liberal education in the professions. That is, the need to develop and hone critical thinking skills and higher order thinking; establish contexts of inquiry and develop values that are appropriate to the profession.

Solving given medical problems was viewed as a way in which residents learned the complexities and ambiguities of professional responsibilities. They, in fact, exemplified medical problem based learning ${ }^{15}$ in real-life, anaesthesia situations.

The qualitative data generated by analysis of the transcribed interviews indicate that the Anaesthesia teachers interviewed functioned at the higher relativistic/Commitment levels of Perry's epistemological schema and carry to the teaching/learning situation a perspective that encourages higher levels of cognitive complexity. Although none of them discussed residents as moving through developmental stages there was an awareness of the need to effect cognitive change. They demonstrated what Basseches describes as thinking that "systematically breaks through the constraints associated with closed-system thinking, so the growth of knowledge continues." 3 Translating this to the 'good teacher' context, the teachers challenge residents to break through the memorization mode of thinking that anticipates certainty (which is often acquired by rigid, didactic teaching in previous educational experiences); the challenge is to accept and cope with the uncertainties and complexities that are part of the practice of anaesthesia with the understanding that learning is a life-long commitment.

\section{Limits}

Our research is limited by the selection of "good teachers" and offers no comparison with other teaching within the Department or other general studies. This was a deliberate attempt to identify some of the characteristics of the selected anaesthesia teachers but we acknowledge that further studies are required to ascertain the characteristics of all teaching methods within the Department. However, the results of our study give a depiction of characteristics to be modelled and provide a foundation for the design of relevant Faculty Development for the Department of Anaesthesia. 


\section{References}

1 Des Marchais JE. From traditional to problem-based curriculum: how the switch was mae at Sherbrooke, Canada. Lancet 1991; 338: 234-7.

2 Perry WG Jr. Intellectual and Ethical Development. Troy, Mo: Holt Rinehart and Winston, 1972.

3 Basseches $M$. Dialectical Thinking and Adult Development. New Jersey: Ablex, 1988.

4 Sinnot JD. Postformal reasoning: the relativistic stage. In: Commons $\mathrm{M}$, et al. (Eds.). Post Formal Operations. New York: Praeger, 1993.

5 Fischer $K W$. A theory of cognitive development: the control and construction of hierarchies of skills. Psychological Review. 1980; 87: 477-531.

6 Cleave-Hoge D, Bayliss C, Cormack D, Murray R, Taylor I. Physicians' views on the value of basic science to clinical practice. Presented at ACMC/CAME Toronto conference, 1990.

7 Severy LJ. Procedures and issues in the measurement of attitudes. ERIC Clearinghouse on Tests, Measurements and Evaluation. Education Testing Service, Princeton, New Jersey: 1974.

8 Cleave-Hogg D, Muzzin L. Developmental levels of entering medical and pharmacy students: considerations for admissions selection policies and curriculum change. In: Demick J, Miller PM (Eds.). Development in the Workplace. London: Lawrence Erlbaum Assoc., 1993: 55.

9 Cleave-Hogg D, Rothman AI. Discerning views. Medical students' perceptions of their learning environment. Evaluation and the Health Professions 1991; 14: 456-74.

10 Delworth U, Piel E. Students and their institutions. In: Parker CA (Ed.). Encouraging Development in College Students. Minn: University of Minnesota Press, 1978.

11 Goertz JP, LeCompte MD. Ethnography and Qualitative Design in Educational Research. Orlando: Academic Press, 1984.

12 Denzin NK, Lincoln YS. Handbook of Qualitative Research. London: Sage, 1994.

13 The Ethnograph. An interactive, menu driven computer program designed to help a qualitative researcher code, recode, sort and report data. Colorado: Qualis Research Associates, 1988.

14 Armour RA, Furmann BS. Confirming the centrality of liberal learning. In: Curry L, Wergin JF \& Assocs. Educating Professionals. San Francisco: Jossey-Bass Publishers, 1993.

15 Barrows HS, Tamblyn R. Problem Based Learning: An Approach to Medical Education. New York: Spinger, 1980. 